\title{
Sweet Potato (Ipomoea batatas L.): a Versatile Raw Material for the Food Industry
}

\section{Daniele Bach ${ }^{1}$}

https://orcid.org/0000-0001-9208-4624

Ana Cláudia Bedin 1

https://orcid.org/ 0000-0002-6844-1983

Luiz Gustavo Lacerda ${ }^{1}$

https://orcid.org/0000-0002-4689-5431

Alessandro Nogueira ${ }^{1}$

https://orcid.org/0000-0001-7671-3056

\section{Ivo Mottin Demiate ${ }^{1^{*}}$}

https://orcid.org/ 0000-0002-5609-0186

${ }^{1}$ State University of Ponta Grossa, Graduate Program in Food Science and Technology, Ponta Grossa, Paraná, Brazil.

Editor-in-Chief: Paulo Vitor Farago

Associate Editor: Paulo Vitor Farago

Received: 2020.09.01; Accepted: 2020.10.01.

*Correspondence: demiate@uepg.br Phone: +55 423220 3268. (I.M.D.).

\section{HIGHLIGHTS}

- Sweet potatoes (SP) are cultivated worldwide and feed millions of people, mainly in developing countries.

- SP composition includes starch and other carbohydrates, which may change during postharvest and processing.

- SP may serve as source of slowly digestible and resistant starch and other ingredients for the food industry, including bioactive compounds with potential for promoting health benefits.

Abstract: Sweet potato (SP) starchy roots have a broad range of colors, high-quality nutritional composition including bioactive substances (anthocyanins and $\beta$-carotene), vitamins, minerals, dietary fiber and starch. Several studies report the versatility of this root crop as part of the human diet and its possible health benefits. In this review the SP chemical composition, nutritional properties and its potential use in food processing for developing nutritious and healthy products are explored. Due to the adaptation of sweet potatoes to several agricultural managing conditions, accepting low technology /low cost with reasonable performance, it has called attention as a strong candidate of accessible functional food market.

Keywords: starch; tuber crop; flour; food ingredient; bioactive compounds. 


\section{INTRODUCTION}

Sweet potatoes (Ipomoea batatas L.), from Convolvulaceae family, have great genetic diversity offering many different sensory aspects including a broad range of colors (pulp and peel), taste and texture for the consumers. This tuberous crop is cultivated for the nutritional value of its starchy roots and also because it adapts to several cultivation conditions without special needs or elevated manage costs when compared with potato (Solanum tuberosum), for example. Although the sweet potato cultivation is spread worldwide $[1,2,3]$, Asia and Africa account for around $85 \%$ of the global production [4]. World production of sweet potatoes is reported to be 105 million metric tons/year $[5,6]$.

Originated from Latin America, its cultivation is made in more than 100 countries, with China accounting for more than $75 \%$ of total production; some African countries are also important producers, mainly Uganda and Nigeria that harvest around 3\% of the global production [7,5]. Sweet potato roots are used mainly as direct food for millions of people, with some amount being processed by the food industry or used for animal feeding $[3,8,9]$. In Brazil sweet potatoes have great genetic diversity and are frequently present in family farming due to wide adaptability, tolerance towards drought, rusticity and easiness of cultivation with production throughout the country totaling 740,000 metric tons harvested in 2018 [5].

The United States are big traders of sweet potatoes and are in the eighth position in global ranking of the producers. North Carolina is the main producer among the North American states, responsible for $40 \%$ of their national harvest [10].

Even though sweet potatoes are grown in many places, only $1 \%$ is marketed with Canada, United Kingdom, Netherlands and Japan, which are the main importers. The United States are the most important exporters accounting for $44 \%$ of such trade [5].

Sweet potato can be considered an ancient crop, relevant for many countries as source of energy for human diet. It outstands as one of the main food crops together with cereals (rice, wheat and corn), legumes (soybeans, dry beans, peas) and other tubers (cassava and potato), generally occupying the third place when considering the production value and the fifth place in caloric importance for the human diet $[3,1,8]$.

This review aims to report and discuss aspects involving the chemical composition, nutritional value and the development of new products (foods and beverages) based on sweet potato as the main raw material.

\section{Sweet potato cultivation}

The sweet potato plant has a long life cycle (up to 36 months), but the maturity of its roots is reached in only four months with staggered harvesting starting after root maturation $[11,8]$. Sweet potato plant growing divides in three stages. During the first stage, aerial part and the peripheric roots develop. The tuberous root formation begins in the second stage with starting of nutritious reserve accumulation. Roots volume increases with change in consistency and they become fleshy. The third stage comprises the complete development of the tuberous roots, with intense storage of starch and other photosynthetic compounds $[12,13]$.

This crop can be produced in very distinct cultivation levels even with low technology and minimal supervision. Therefore, it attracts attention from small farmers favoring their profits especially if cultivated in organic system with applications both as raw material for industrial processing as well as food for the families and the byproducts / discarded roots for animal feeding [11,7].

Post-harvest losses are a concern for this crop [14,6]. During harvest and also after this stage improper handling of the high-moisture roots can cause mechanical damage impairing quality and increasing losses due to microbial contamination. In developing countries, with warmer and humid climate, the larger postharvest losses are estimated (15-65\%). An alternative to prevent such losses could be the processing of roots to make dry flour.

These tropical origin roots cannot be stored at low temperatures $\left(4-10^{\circ} \mathrm{C}\right)$ because they are susceptible to chilling damage. Storage should be made at temperatures above $13^{\circ} \mathrm{C}$, but in warmer conditions starch content can decrease and sugar levels increase in some varieties [2].

There is another big issue related to food losses, the farm-level losses. Those values are difficult to estimate because they are not as visible as consumer food waste [15]. Even in the United States and in other developed countries, the data from farm-level losses are unreliable due to lack of field-based measurement. In general, interviews with farmers are performed but not always bring real and reliable data. Harvesting vegetable crops as sweet potatoes can cost a lot of money and produce with size, shape or any defect is left in the field during this step. According to Johnson and coauthors [15], which have developed a field-based study in North Carolina (USA), very high amounts (mean value of $42 \%$ ) of marketable/edible sweet potato roots remain unharvested and are lost due to commercial issues. Considering that the crop produce 
remaining in field is mostly edible, opportunity exists for use in foodservice, processing, alternative markets or emergency food supply.

Popular and valued by several populations since ancient times, sweet potato was already considered a special "hunger relief" food for the poorer populations [6]. This root crop has saved people from different regions from hunger and catastrophes. In China during the 1960's, it was the food that has avoided the death of millions. In Japan it was the relief when typhoons destroyed rice fields throughout the country. In Uganda, in the 1990's, with very serious phytosanitary issues in their cassava fields, sweet potato was also the food that has fed millions [4].

In order to improve the nutritious quality of food crops, research has been performed for decades. In the specific case of sweet potato, important benefits were described associated with its caloric value, dietary fiber and resistant starch contents as well as the presence of important phytochemicals (anthocyanins, carotenoids) [16]. Although the number of scientific studies on this root crop is increasing there is still limited consumption if compared with other main food crops. An alternative for increasing the use of sweet potatoes would be its incorporation in baked foods, in ready-to-eat dishes, development of ethnic recipes and the processing into flour that could partially replace wheat flour in countries where this cereal is scarce or expensive $[14,17,6]$.

\section{Chemical composition of sweet potatoes}

Sweet potato is an important source of nutrients for human diet and also contains bioactive compounds potentially beneficial to health with special interest for the functional food market $[10,18]$.

Sweet potato varieties with higher dry matter content also have higher percentages of starch and soluble carbohydrates and larger starch granule size after storage of the roots. Smaller starch granules tend to degrade faster during storage of the roots [2].

Carbohydrates are the most abundant constituents from SP roots, providing energy for human diet (Table 1). Dietary fiber values (1.3-3.8\%) and glycemic index (63 to 66) are better than those reported for potato (Solanum tuberosum L.). Generally, dietary fiber intake is below the desired level (14 g/1000 kcal or 23-38 $\mathrm{g} /$ day). Therefore, the development of products or ingredients rich in dietary fiber is increasing and this tropical tuber crop can potentially improve the dietary fiber and also the contents of other nutrients in processed foods $[9,8]$.

High moisture level and low lipid content $(0.2 \%)$, with protein levels ranging from 0.5 to $2.2 \%$ are reported for SP [19,9]. Generally, starch content ranges from 15 to $26 \%$ in wet weight basis [20].

Depending on the SP pulp color distinct vitamin contents are present (mainly A, B and C); in general, $\beta$ carotene, anthocyanins, phenolic compounds, folic acid and minerals (potassium, calcium, magnesium, sodium, phosphorous and iron) may be present. High contents of chlorogenic acid, a family of esters formed from cinnamic and quininic acids can also be found $[21,3,8]$.

Fermentable sugars (glucose, fructose and sucrose) are present in SP pulp that also contains vitamin C in concentrations reported as twice those from common potatoes [8]. SP can be considered as a good source of $\beta$-carotene (vitamin A precursor), with reported concentrations of around $18 \mathrm{mg} / 100 \mathrm{~g}$. This important bioactive prevents vitamin A shortage in the organism avoiding serious diseases (mainly the night blindness) and also has antioxidant property and can aid in prevention of heart diseases and cancer. It also contains certain phenolic acids, especially hydroxycinnamic acid $[22,10]$.

The ingestion of $100-125 \mathrm{~g}$ of yellow flesh SP per day will provide the recommended dietary allowance of vitamin A for children younger than five years old [7]. In Asian and African countries this starchy root is reported to help avoiding vitamin deficiency in children and women.

The purple flesh SP is rich in acylated anthocyanins and other phenolic compounds with antioxidant activity with good bioavailability, presenting anti-inflammatory action. These anthocyanins are not stable but have beneficial effects to human health. This deep colored SP with high levels of anthocyanins can be used as natural colorant to the food industry $[10,23,24]$.

Some studies show that anthocyanins can eliminate free radicals, have positive effects in memory, decrease blood glucose levels and are able to inhibit growing of certain types of cancer cells [25,24]. 
Table 1. Nutritional value of raw SP.

\begin{tabular}{lcl}
\hline Nutrient & Amount & Unity $(/ \mathbf{1 0 0 g})$ \\
\hline Water & $69.5-81.3$ & $\mathrm{~g}$ \\
Energy & $86.0-106.0$ & $\mathrm{kcal}$ \\
Protein & 1.5 & $\mathrm{~g}$ \\
Lipids & 0.1 & $\mathrm{~g}$ \\
Carbohydrates & $21.3-22.0$ & $\mathrm{~g}$ \\
Dietary fiber & 3.0 & $\mathrm{mg}$ \\
Calcium & $39.0-63.0$ & $\mathrm{mg}$ \\
Iron & $0.6-1.3$ & $\mathrm{mg}$ \\
Magnesium & $15.0-37.0$ & $\mathrm{mg}$ \\
Phosphorous & $28.0-51.0$ & $\mathrm{mg}$ \\
Potassium & $191.0-337.0$ & $\mathrm{mg}$ \\
Zinc & $0.3-0.7$ & $\mu \mathrm{RA}$ \\
Vitamin A & $1.0-1371.0$ & $\mathrm{mg}$ \\
Vitamin B & 82.5 & $\mathrm{mg}$ \\
Vitamin B2 & 47.3 & $\mathrm{mg}$ \\
Vitamin B5 & 0.55 & $\mathrm{mg}$ \\
Vitamin B6 & 0.21 & $\mathrm{mg}$ \\
Vitamin C & 3.0 & \\
\hline
\end{tabular}

RAE $=$ Retinol activity equivalent

\section{Source: $[26,27]$ (adapted)}

Orange fleshed sweet potato (OFSP) is considered one of the most successful cases of biofortification of a staple food crop in the world. In Africa vitamin A deficiency is still a serious nutritional concern and OFSP consumption delivers $\beta$-carotene to the population alleviating this problem [27]. Consumers from South Africa prefer floury/starchy sweet potatoes, which have higher dry matter content. Sweetness and maltose content also seem to be desirable for South African consumers.

Purple fleshed sweet potato has potential for use as source of natural colorants and its antioxidant activity drives this food crop to be included as raw material for the functional food industry [28].

\section{Sweet potato processing}

Traditionally, the consumption of SP occurs as cooked roots but its use as ingredient in food formulations, ready-to-eat products and beverages is growing up. The direct use of SP as food is still the most abundant and only a limited percentage of the roots is utilized for animal nutrition and for industrial applications [3, 29].

Boiling, steaming, roasting and frying are the most frequent ways to cook sweet potatoes for human consumption and each of those thermal treatments can benefit their sensory quality. Roasting of Chinese cultivars of sweet potatoes was studied as affecting color and the contents of sugar, amino acids and volatile compounds. Roasting contributed for chemical and sensory changes (mainly associated with the Maillard reaction) as well as partial enzymatic hydrolysis of starch, increasing the maltose contents by roughly 14 to 160 times if compared to its original percentage in dry weight of uncooked roots [30].

Pulsed electric field (PEF), a non-thermal technology was applied to sweet potato roots, also known as Kumara in New Zealand, in order to evaluate its effects on structure and frying quality [31]. The results showed that PEF was able to improve the texture and facilitate frying at lower temperature and with less absorption of frying oil by the Kumara chips.

Among several varieties of SP cultivated in different regions from the world, those of different pulp colors (purple, yellow/orange, white/beige) are considered potential raw materials for the industrial processing. Their differences surpass the color and also involve physicochemical, nutritional and antioxidant properties, and the right selection for industrial processing is a key-factor. Varieties with light color pulp, for example, contains the highest percentages of starch and are though recommended for processors interested in that polysaccharide [6].

Primary processing includes proper storage and handling of the fresh roots. Classification is one of the most relevant post-harvest operations, in which the roots are separated by size, shape, weight, uniformity and presence of defects. One of the most important handling steps is known as cure, which promotes wound healing of surface injuries that were produced during harvest. Performed in the farm to retard deterioration 
by exposing the roots to mild temperature for a specified time to allow the auto cure of the roots. Raw SP roots can be stored for two to three weeks if not consumed just after harvest [6].

If secondary processing is made value-added products can be obtained. The production of SP flour, for example, involves bleaching (with sulfur dioxide) previous to (sun- or oven-) drying step for avoiding undesirable enzymatic browning [32,6].

Another method for preserving SP roots involves fermentation in a similar way as carried out for other vegetables, resulting in peculiar sensory quality [33,34 ].

In Japan, besides being directly consumed as cooked roots and for livestock, manufacturing of starch, beverages and domestic products is also important for the sweet potato production chain. Starch is the main component of the reserve roots and drives most SP uses, affecting the texture of cooked roots and together with sugars (glucose, fructose, sucrose and maltose), the eating quality [35].

Alternative starches are of great interest because they can replace some types of modified starches in the food industry. Each starch will present distinct technological properties that depend on the genetic background as well as on environmental conditions during crop development. Sweet potato starch has been studied and presents unique properties, which can be explored benefiting and broadening the starch market [36]. SP starch was pregelatinized by spray-drying with changes in the granules that have lost partially or totally the crystallinity depending on the degree of gelatinization [37]. The authors explain that their study was justified by the growing interest of the industry in non-conventional sources of starch, like starch from sweet potato.

\section{Processed Foods}

The high nutritional value and the presence of good levels of polyphenols, antioxidant pigments in SP varieties are calling attention from the consumers; this tuberous root reaches trade needs for functional foods and also the food and beverage industry search for new nutritious and functional ingredients [38].

The main compound found in SP roots is starch and it is the most important industrial commodity to be produced from this raw material; depending on the variety, starch accounts for 50 to $80 \%$ of the roots dry matter [39, 40]. Starch main properties (gelatinization, thermal and rheological behavior) vary depending on SP genetic background. SP starch granules have diameters and amylose contents in between those reported for cassava and potato starches [24,36]. Sweet potato starch differs from cereal starches (A-type) in several properties, including its C-type polymorph under X-ray diffraction. Even though, these two starches behaved as compatible polymers when tested using a thermodynamic approach [41]. There are some sweet potato cultivars available only in Japan that present B-type polymorph and the lowest gelatinization and pasting temperatures reported so far (50.1 - $52.2{ }^{\circ} \mathrm{C}$ and $58.4-58.8 \stackrel{\circ}{\circ} \mathrm{C}$, respectively) [35]. Energy saving gelatinization would be one of the great advantages of using those Japanese cultivars in food processing and also as feedstock for production of bioethanol.

Knowing of the physicochemical and technological properties of the starch will result in the best industrial uses with the desired results and high quality products [36].

Processing promotes extended availability of sweet potatoes as well as value-adding. Flours, purees, flakes and other products can be made and used directly or as ingredients in breadmaking and confectionary, for example [27].

Studies on the production of bread and bakery products with gluten-free flours are also relevant for the use of SP. In general, flour mixes are made with locally produced gluten-free cereals, tuber and legumes and are advantageous for developing countries in which wheat is not available in large amounts, being imported or a high costing crop [42].

In addition to the economic advantage, incorporating SP flour in breadmaking can also result in nutritional benefits. If the right variety is used, containing yellow/orange pulp, for example, it can deliver $\beta$-carotene and also serving as a natural colorant to the bread crumb; the purple fleshed SP can also be used as a natural colorant and can also be beneficial to human health. These flours have important chemical characteristics and can be used together with wheat flour to alter rheological and sensory quality [25, 43,36,44]. An example of the effect of chemical composition on breadmaking is related to the presence of sugars like maltose, sucrose, fructose, glucose and some fructooligosaccharides, which even in low concentrations favor the processing of long-time fermentation baking products [14].

Another way of incorporating SP in bread doughs is by cooking the roots and producing a puree. This puree has around $80 \%$ moisture and low contents of protein and lipids but considerable levels of fiber and minerals [9]. SP that is not directly consumed cooked in human diet can be used to produce flour or starch. Studies reporting fermented foods from SP are available (Table 2). In the African country Gana, for example, 
the traditional cassava fermented flour known as Gari was produced replacing the original raw material by SP [45]. The fermentation process in which predominates lactic acid bacteria influences the sensory quality in several ways with acidification, for example (lactic acid produced will cause $\mathrm{pH}$ drop) [33].

The purple fleshed SP that is rich in anthocyanins is frequelntly used as a raw colorant, because those colored compounds are water soluble and safe for ingestion. This pigment, however, degrades under light, $\mathrm{pH}$ changes, temperature, oxygen, ascorbic acid and sugar. The main anthocyanins from thee purple flesh $\mathrm{SP}$ are cyanidin and peonidin [46].

Besides the food uses of SP roots, the vegetative parts of the crop (leaves and stems) and also those roots without commercial value (bad shaped, too big or too small) can be fermented for animal feeding in many countries, like China and Japan $[47,19]$.

The wastes generated by SP flour processing are being used as cheap substrates in bioprocess technology for producing microbial enzymes, for example [48].

The continuous increase of the demand for bio-renewable fuels together with the alternative sources of energy generation, poses SP bioethanol as a potential bioproduct [49].

Sweet potato starch outstands in East and South Asia as an important ingredient for oriental foods as noodles and vermicelli. China is the leading country in the commercial production of SP starch, but processing technology still needs to be improved. The largest sweet potato starch factory in China produces 120,000 metric tons of starch, 70,000 metric tons of noodles, and 10,000 tons of vermicelli [28].

The main reported use of sweet potato starch is as a cheaper ingredient for noodle production, replacing mung bean starch. Other applications described include the production of thermoplastic materials (biofilms), component of pharmacological and medical products (binding agent for tablets, controlled drug release carriers) and source of nutrients in several bioprocesses (maltose, bioethanol, lactic acid, cyclodextrin, trehalose). Many other possibilities are still underexplored for SP starch when comparing with the largely available starch sources [50].

Innovative foods are continuously under development estimulated by consumer's demands for nutritious, healthy and tasty products. 3D printing is an emerging technology adopted by many industrial sectors, including the food processing chain. Similar to 3D printing, the concept of 4D printing was introduced in the last decade and involves smart materials that will change over time due to environmental effects, like $\mathrm{pH}$ values, light exposition, temperature and so on. 4D printing of mashed potato together with purple sweet potato puree with spontaneous color channge was promoted and a three-dimensional multi-color ready-toeat food was developed. The color of the printed product, rich in anthocyanins, would change gradualy with storage time as a response to $\mathrm{pH}$ values [51].

Sweet potato starch in vitro digestibility was investigated and improved by enzymatic selective hydrolysis [52] and heat moisture treatment [53]. Considered a cheap and available source of starch, increased levels of slowly digestible and resistant starch (SDS and RS, respectively) were produced by using fungal $\alpha$-amylase from Aspergillus oryzae, maltogenic a-amylase from Bacillus sp and pullulananse from Bacillus subtilis [52] .

An optimized SDS production from sweet potato starch was described as being the use of moisture level at $22.8 \%$, at $113^{\circ} \mathrm{C} / 8.6 \mathrm{~h}$ and the authors suggested possible technological uses of this thermally modified starch in low glycemic index processed foods such as crackers and cookies [53]. Sweet potato is a major source of opportunities for the food and beverage industry as well as for other industrial applications, including bioprocess technology and biofuel (Table 2). 
Table 2. Sweet potato products.

The fortification of yellow/orange fleshed SP was promoted by adding anthocyanins and polyphenols

[10] from fruits and from purple fleshed SP. The study has evaluated the antioxidant capacity, nutritional and sensory quality as well as the polyphenol stability during the shelf life of the flour.

[54] Rheological characterization of SP doughs was made for SP varieties cultivated in Malaysia.

Flour analysis

\section{[55]}

[48]

\section{Sweet potato flour}

Bakery products
[43] Partial replacing of wheat flour by SP flour for production of breads was studied. Nutritional and sensory quality of the final products were analyzed.

[14] Replacing of wheat flour by orange fleshed SP flour in special long fermentation sweet breads was studied.

[56] Evaluation of the effect of using purple sweet potato powder (PSPP) together with $\alpha$-amylase and hemicellulase on the texture and structure of dough and breads. The bread crumb hardness, moisture, cohesivity were analyzed to understand the effects of PSPP and enzymes on the bread quality.

[57] The addition of purple sweet potato powder and enzymes ( $\alpha$-amylase and hemicellulase) were tested in bread formulation and texture and retrogradation as well as the crumb structure of the final product were analyzed.

Development of noodles with SP flour in formulation aiming at dietary fiber increase and to have use for this raw material.

[59]

\section{Modification of} starch

\section{Sweet potato} starch

[60]
Gelling properties and structural changes in SP starch modified by heat moisture treatment (HMT) were studied.

Corn starch was replaced by SP modified starch as a thickening agent in this study.

Cassava starch was replaced by SP starch in different Alternative
ingredient levels and physicochemical and sensory analyses were performed.

Pasta/noodles

[62] The moisture control was studied in noodles made with SP starch. 
[63] Purple sweet potato powder was used for making fresh noodles and general quality analyses were carried out.

[64] The production of antioxidant extracts from orange SP and addition in noodles was studied.

Sweet potato starch
[65] Blends of wheat flour and SP flour were used for producing noodles.

[66] The effect of fermentation of SP starch, using Lactobacillus plantarum, on noodle production was studied. Physicochemical analyses were made in the produced noodles, considering the role of fermentation inn improving the quality of the noodles.

[67] Stable SP puree with longer shelf life was reported as a basic ingredient for breads, cakes and porridges.

[68] The level of compliance to Good Manufacture Practices and levels of microbial contamination in sweet potato (orange flesh) puree was studied.

[9] The use of SP puree was tested in brownie. The authors had the objective of incorporating dietary fiber to this type of cake. Physicochemical and sensory analyses were performed.

Pasta/noodles

[69] Physicochemical and sensory properties of noodles made with SP puree blended with wheat flour were studied.

[70] Potato and SP flakes were studied from thermodynamic point of view in order to understand their behavior and stability during storage.
Sweet potato flakes

Flakes

[71]

Temperature and packaging effects on the shelf life of purple sweet potato nectar were studied.

[25] The effects of high hydrostatic pressure (HHP) and of high temperature short time (HTST) treatments were

Sweet potato nectar

Nectar

[72] storage period.

physicochemical properties, anthocyanins, total phenolic compounds, antioxidant capacity, color en the presence of microorganisms. The analyses were performed right after processing and also during the Extruded products were enriched with protein, fiber and bioactive compounds. Physicochemical and sensory properties were studied.

[73] This study has evaluated the effect of the type of package on the stability of rich in carotenoids fried SP.

Sweet potato snacks

Snacks

[74] The precursors of acrylamide in fried purple SP were studied. The effect of the unsaturation of the frying oil and its effect on the formation of acrylamide was investigated.

\section{Sweet potato} snacks

Snacks
Study of lychee snacks with purple sweet potatoes, using microwave drying techniques. 
[76] Evaluation of the characteristics of sweet potato fries, using vacuum frying.

[11] This study discusses that the demand for sweet potatoes for both subsistence and commercialization, including bioethanol, depends on a sustainable

Biofuel

Biofuel production system.

[77] Study on the industrial cultivar CX-1 offers superior potential for feed and fuel.

\section{Natural colorant}

from sweet potato

Colorant
[23]

[78]

\section{Ration}

In this study, methods for extracting colorant from purple sweet potato are described.

78] Study on the reduction of pollution of residues generated by the sweet potato beverage industry for the environment and the transformation of these residues, mixed with peanut shells, into biomass protein to be used as animal feed.

Development of fermented red wine from purple sweet potatoes with Saccharomyces cerevisiae, with good sensory acceptance and rich in antioxidants. Wine produced from purple fleshed SP presented anthocyanins that were stable during storage.

[81] Alcoholic beverage was produced containing anthocyanins with antioxidant, anticarcinogenic and

Alcoholic beverage

[82] antihypertensive activities.

Beverage made from sweet potato

\begin{tabular}{ccl}
\hline Juice & {$[84]$} & $\begin{array}{l}\text { Production of purple sweet potato juice, with better } \\
\text { antioxidant activity and anthocyanin levels. }\end{array}$ \\
\cline { 2 - 4 } Shochu & {$[85]$} & $\begin{array}{l}\text { Recovery of polyphenols extracted from purple sweet } \\
\text { potato extract. }\end{array}$ \\
\hline Gari & {$[86]$} & $\begin{array}{l}\text { Analysis of the effect of diglycoside-specific } \beta- \\
\text { primeverosidase on flavor formation during the } \\
\text { manufacture of sweet potato shochu. }\end{array}$ \\
\hline Juice (lactic & {$[45]$} & $\begin{array}{l}\text { Fermented product, use of sweet potatoes instead of } \\
\text { cassava, obtaining a sensorially similar product to that } \\
\text { used with cassava. }\end{array}$ \\
\hline Yogurt & {$[87]$} & $\begin{array}{l}\text { This study has investigated the lactic fermentation as } \\
\text { a way to improve SP beverages for human nutrition } \\
\text { and health. }\end{array}$ \\
\hline Pickles & {$[88]$} & $\begin{array}{l}\text { Studies related to the addition of sweet potatoes to } \\
\text { ferment together with milk, thus improving nutritional } \\
\text { quality (dietary fibers, starch, minerals and vitamins). }\end{array}$ \\
\hline & {$[22]$} & $\begin{array}{l}\text { Production and analysis of SP pickles were the } \\
\text { objectives of this study. }\end{array}$ \\
\hline & {$[33]$} & $\begin{array}{l}\text { Potato pickles was produced using a mixed culture of } \\
\text { actobacillus plantarum and } \\
\text { mesenteroides. }\end{array}$ \\
\hline & {$[34]$} & $\begin{array}{l}\text { Evaluation of sensory attributes (appearance, color, } \\
\text { aroma, texture and acidity) of sweet potato pickles } \\
\text { was performed with possible consumers. }\end{array}$ \\
\hline
\end{tabular}




\section{CONCLUSION}

The available bibliography so far allowed us to consider historical and economy aspects as well as chemical composition, nutritional potentiality of sweet potatoes from different pulp colors and varieties. It becomes evident that SP is a major food crop throughout the world, but with larger production and consumption in Asia and Africa. There are several studies that show the importance of this crop for the rural areas of developing countries as well as the great potential of SP roots to be traded as functional foods. Some examples of industrial uses of SP were highlighted in the present review mainly by the food and beverage sector due to the high nutritional and bioactive quality of its roots.

Funding: Coordenação de Aperfeiçoamento de Pessoal de Nível Superior (CAPES/Brazil - DS - PROAP) and Conselho Nacional de Desenvolvimento Científico e Tecnológico (CNPq/Brazil - Proc. no 304260/2019-3).

Acknowledgments: The authors have received financial support and scholarships from the Coordenação de Aperfeiçoamento de Pessoal de Nível Superior (CAPES/Brazil) and IMD (Proc. no 304260/2019-3), LGL and AN are research fellows from the Conselho Nacional de Desenvolvimento Científico e Tecnológico (CNPq/Brazil) and are thankful to these official agencies.

Conflicts of Interest: The authors declare no conflict of interest.

\section{REFERENCES}

1. Carballo Pérez I, Mu TH, Zhang M, Ji LL. Effect of high hydrostatic pressure to sweet potato flour on dough properties and characteristics of sweet potato-wheat bread. Int. J. Food Sci. Technol. 2018; 53(4): 1087-94. https://doi.org/10.1111/ijfs.13687

2. Niu S, Li XQ, Tang R, Zhang G, Li X, Cui B, Haroon M. Starch granule sizes and degradation in sweet potatoes $\begin{array}{llllll}\text { during storage. } & \text { Postharvest } & \text { Biol. } & \text { Technol. } & \text { 130: }\end{array}$ https://doi.org/https://doi.org/10.1016/j.postharvbio.2019.01.004

3. Trancoso-Reyes N, Ochoa-Martínez LA, Bello-Pérez LA, Morales-Castro J, Estévez-Santiago R, Olmedilla-Alonso B. Effect of pre-treatment on physicochemical and structural properties, and the bioaccessibility of $\beta$-carotene in sweet potato flour. Food Chem. 2016: https://doi.org/https://doi.org/10.1016/j.foodchem.2016.01.047

4. El Sheikha AF, Ray RC. Potential impacts of bioprocessing of sweet potato: Review. Crit. Rev. Food Sci. Nutr. 2017: 57(3), 455-71. https://doi.org/10.1080/10408398.2014.960909

5. Food and Agriculture Organization of the United Nations - FAOSTAT - [citado em 07 de março de 2020]. Disponível em: http://www.fao.org/faostat/en/\#data/QC

6. Vithu P, Dash SK, Rayaguru K. Post-Harvest Processing and Utilization of Sweet Potato: A Review. Food Rev. Int. 2019, 35(8), 726-62. https://doi.org/10.1080/87559129.2019.1600540

7. Sugri I, Maalekuu, BK, Gaveh E, Kusi F. Sweet Potato Value Chain Analysis Reveals Opportunities for Increased Income and Food Security in Northern Ghana. Adv. Agric. 2017: 1-14. https://doi.org/10.1155/2017/8767340

8. de Albuquerque TMR, Sampaio KB, de Souza EL. Sweet potato roots: Unrevealing an old food as a source of health promoting bioactive compounds - A review. Trends Food Sci. Technol. 2019: 85, 277-86. https://doi.org/https://doi.org/10.1016/j.tifs.2018.11.006

9. Selvakumaran L, Shukri R, Ramli NS, Pak Dek MS, Wan Ibadullah WZ. Orange sweet potato (Ipomoea batatas) puree improved physicochemical properties and sensory acceptance of brownies. J. Saudi Soc. Agric. Sci. 2019: 18(3), 332-6. https://doi.org/10.1016/j.jssas.2017.09.006

10. Grace MH, Truong AN, Truong VDen, Raskin I, Lila MA. Novel value-added uses for sweet potato juice and flour in polyphenol- and protein-enriched functional food ingredients. Food Sci. Nutr. 2015: 3(5), 415-24. https://doi.org/10.1002/fsn3.234

11. Widodo $Y$, Wahyuningsih S, Ueda A. Sweet Potato Production for Bio-ethanol and Food Related Industry in Indonesia: Challenges for Sustainability. Procedia Chem. 2015: 14, 493-500. https://doi.org/10.1016/j.proche.2015.03.066

12. Queiroga RCF, Santos MA, Menezes MA, Vieira CPG, Silva MC. Physiology and yield of sweet potato cultivars depending on harvesting time. Hort. Bras. 2007: 25, 3. http://dx.doi.org/10.1590/S0102-05362007000300010

13. Erpen L, Streck NA, Uhlmann LO, Freitas PO, Andriolo JL. Tuberization and yield of sweet potato as affected by planting date in a subtropical climate. Bragantia. 2013:73,4. http://dx.doi.org/10.1590/brag.2013.050

14. Aparecida Pereira AP, Pedrosa Silva Clerici MT, Schmiele M, Gioia Júnior LC, Nojima MA, Steel CJ, Nabeshima EH. (2019). Orange-fleshed sweet potato flour as a precursor of aroma and color of sourdough panettones. LWT Food Sci. Technol. June 2018: 101,145-51. https://doi.org/10.1016/j.Iwt.2018.10.091 
15. Johnson LK, Dunning RD, Gunter CC, Dara Bloom J, Boyette MD, Creamer NG. Field measurement in vegetable crops indicates need for reevaluation of on-farm food loss estimates in North America. Agric. Syst. 2018: 167, 136-42. https://doi.org/https://doi.org/10.1016/j.agsy.2018.09.008

16. Oke M, Workneh TS. A review on sweet potato postharvest processing and preservation technology. Afr. J. Agric. Res. January 2013: 8(40), 4990-5003. https://doi.org/10.5897/AJAR2013.6841

17. Santiago DM, Matsushita K, Noda T, Tsuboi K, Yamada D, Murayama D, Yamauchi H. Effect of purple sweet potato powder substitution and enzymatic treatments on bread making quality. Food Sci. Technol. Res. 2015: 21(2), 15965. https://doi.org/10.3136/fstr.21.159

18. Cui R, Zhu F. Effect of ultrasound on structural and physicochemical properties of sweetpotato and wheat flours. Ultrasonics Sonochemistry. Feb 2020, 105118. https://doi.org/10.1016/j.ultsonch.2020.105118

19. Akoetey W, Britain MM, Morawicki RO. Potential use of byproducts from cultivation and processing of sweet potatoes. Cienc. Rural. 2017: 47(5). https://doi.org/10.1590/0103-8478cr20160610

20. Wang H, Yang Q, Gao L, Gong X, Qu Y, Feng B. Functional and physicochemical properties of flours and starches from different tuber crops. Int. J. Biol. Macromol. 2020: 148, 324-32. https://doi.org/10.1016/j.ijbiomac.2020.01.146

21. Finotti E, Bersani E, Del Prete E, Friedman M. A functional mathematical index for predicting effects of food processing on eight sweet potato (Ipomoea batatas) cultivars. J. Food Compos. Anal. 2012: 27(1), 81-6. https://doi.org/10.1016/j.jfca.2012.04.001

22. Yuliana N, Nurdjanah S, Margareta M. The Effect of a Mixed-Starter Culture of Lactic Acid Bacteria on the Characteristics of Pickled Orange-Fleshed Sweet Potato L.) (Ipomoea batatas). Microbiol. Indones. 2013:7(1),18. https://doi.org/10.5454/mi.7.1.1

23. Velmurugan P, Kim JI, Kim K, Park JH, Lee KJ, Chang WS, Oh BT. Extraction of natural colorant from purple sweet potato and dyeing of fabrics with silver nanoparticles for augmented antibacterial activity against skin pathogens. J. Photochem. Photobiol., B. 2017 Jun:173,571-9. https://doi.org/10.1016/j.jphotobiol.2017.07.001

24. Na JH, Kim HR, Kim Y, Lee JS, Park HJ, Moon TW, Lee CJ. Structural characteristics of low-digestible sweet potato starch prepared by heat-moisture treatment. Int. J. Biol. Macromol. October 2019: 151, 1049-57. https://doi.org/10.1016/j.jijbiomac.2019.10.146

25. Wang Y, Liu F, Cao X, Chen F, Hu X, Liao X. Comparison of high hydrostatic pressure and high temperature short time processing on quality of purple sweet potato nectar. Innovative Food Sci. Emerg. Technol. 2012: 16, 326-34. https://doi.org/10.1016/j.ifset.2012.07.006

26. Laurie S, Faber M, Adebola P, Belete A. Biofortification of sweet potato for food and nutrition security in South Africa. Food Res. Int. 2015 Jun: 76(P4), 962-970. https://doi.org/10.1016/j.foodres.2015.06.001

27. Laurie SM, Faber M, Claasen N. Incorporating orange-fleshed sweet potato into the food system as a strategy for improved nutrition: The context of South Africa. Food Res. Int. 2018 Sept: 104, 77-85. https://doi.org/https://doi.org/10.1016/j.foodres.2017.09.016

28. Wang X, Wang J, Liu H, Zhao L, Wang Y, Wu X, Liao X. Improving the production efficiency of sweet potato starch using a newly designed sedimentation tank during starch sedimentation process. J. Food Process. Preserv. 2020 Jul: 1-10. https://doi.org/10.1111/jfpp.14811

29. Lee H, Kim HS. Isolation and physicochemical property of individual parenchyma cells from mealy sweet potato. Food Sci. Biotechnol. 2020: 29(4), 521-9. https://doi.org/10.1007/s10068-019-00692-8

30. Hou F, Mu t, Ma M, Blecker C. Sensory evaluation of roasted sweet potatoes influenced by different cultivars: A correlation study with respect to sugar, amino acids, volatile compounds, and colors. Inst. Food Sci. Technol. August 2020: 14646. https://doi.org/10.1111/jfpp.14646

31. Liu T, Dodds E, Leong SY, Eyres GT, Burritt DJ, Oey I. Effect of pulsed electric fields on the structure and frying quality of "kumara" sweet potato tubers. Innovative Food Sci. Emerg. Technol. 2017: 39, 197-208. https://doi.org/https://doi.org/10.1016/j.ifset.2016.12.010

32. Albuquerque TMR, Borges CWP, Cavalcanti MT, Lima MS, Magnani M, Souza EL. Potential prebiotic properties of flours from different varieties of sweet potato (Ipomoea batatas L.) roots cultivated in Northeastern Brazil. Food Biosci. 2019 Jun: 36, 100614. https://doi.org/10.1016/j.fbio.2020.100614

33. Panda SH, Panda S, Sivakumar PS, Ray RC. Anthocyanin-rich sweet potato lacto-pickle: Production, nutritional and proximate composition. Int. J. Food Sci. Technol. 2009: 44(3), 445-55. https://doi.org/10.1111/j.13652621.2008.01730.x

34. Sivakumar PS, Panda SH, Ray RC, Naskar SK, Bharathi LK. (2010). Consumer acceptance of lactic acid-fermented sweet potato pickle. J. Sens. Stud. 2010:25(5),706-19. https://doi.org/10.1111/j.1745-459X.2010.00299.x

35. Kitahara K, Nakamura Y, Otani M, Hamada T, Nakayachi O, Takahata Y. Carbohydrate components in sweetpotato storage roots: their diversities and genetic improvement. Breed. Sci. 2017: 67 (1), 62-72. https://doi.org/10.1270/jsbbs.16135 
36. Wang H, Yang Q, Ferdinand U, Gong X, Qu Y, Gao W, Liu M. Isolation and characterization of starch from light yellow, orange, and purple sweet potatoes. Int. J. Biol. Macromol. 2020: 160, 660-8. https://doi.org/10.1016/j.ijbiomac.2020.05.259

37. Santos TPR, Franco CML, Demiate IM, Li XH, Garcia EL, Jane J lin, Leonel M. Spray-drying and extrusion processes: Effects on morphology and physicochemical characteristics of starches isolated from Peruvian carrot and cassava. Int. J. Biol. Macromol. 2018 Jun: 118, 1346-53. https://doi.org/10.1016/j.ijbiomac.2018.06.070

38. Pacheco MT, Hernández OH, Moreno FJ, Villamiel M. Andean tubers grown in Ecuador: New sources of functional ingredients. Food Biosci. 2020 Jun: 35, 100601. https://doi.org/10.1016/j.fbio.2020.100601

39. Gou M, Wu H, Saleh ASM, Jing L, Liu Y, Zhao K, Li W. Effects of repeated and continuous dry heat treatments on properties of sweet potato starch. Int. J. Biol. Macromol. 2019 Jan: 129, 869-77. https://doi.org/10.1016/j.ijbiomac.2019.01.225

40. Harahap E S, Julianti $E$, Sinaga $H$. Utilization of orange fleshed sweet potato flour, starch and residual flour in biscuits making. IOP Conf. Ser.: Earth Environ. Sci. 2020: 454(1). https://doi.org/10.1088/1755-1315/454/1/012120

41. Ding Y, Shen M, Wei D, Xu L, Sui T, Cao C, Zhou Y. Study on compatible characteristics of wheat and purple sweet $\begin{array}{lllll}\text { potato starches. } & \text { Food } & \text { Hydrocolloids. } & 2020: & 107,\end{array}$ https://doi.org/https://doi.org/10.1016/j.foodhyd.2020.105961

42. Julianti E, Rusmarilin H, Ridwansyah Yusraini E. Effect of soybean flour on physico-chemical, functional, and rheological properties of composite flour from rice, sweet potato, and potato. Trop. Life Sci. Res. 2016: 27, 133-8. https://doi.org/10.21315/tlsr2016.27.3.18

43. Mitiku DH, Abera S, Bussa N, AberaT. Physico-chemical characteristics and sensory evaluation of wheat bread partially substituted with sweet potato (Ipomoea batatas L.) flour. Br. Food J. 2018: 120(8), 1764-75. https://doi.org/10.1108/BFJ-01-2018-0015

44. Silva E, Birkenhake M, Scholten E, Sagis LMC, van der Linden E. Controlling rheology and structure of sweet potato starch noodles with high broccoli powder content by hydrocolloids. Food Hydrocolloids. 2013: 30(1), 42 52. https://doi.org/10.1016/j.foodhyd.2012.05.002

45. Oduro I, Ellis WO, Dziedzoave NT, Nimako-Yeboah K. Quality of gari from selected processing zones in Ghana. Food Control. 2000: 11(4), 297-303. https://doi.org/10.1016/S0956-7135(99)00106-1

46. Wulandari A, Sunarti TC, Fahma F, Noor E. Potency of Purple Sweet Potato's Anthocyanin as Biosensor for Detection of Chemicals in Food Products. IOP Conf. Ser.: Earth Environ. Sci. 2018: 147(1). https://doi.org/10.1088/1755-1315/147/1/012007

47. Sun H, Mu T, Xi L, Zhang M, Chen J. Sweet potato (Ipomoea batatas L.) leaves as nutritional and functional foods. Food Chem. 2014: 156, 380-9. https://doi.org/10.1016/j.foodchem.2014.01.079

48. JU D, MU T hua, SUN H nan. Sweet potato and potato residual flours as potential nutritional and healthy food material. J. Integr. Agric. 2017:16(11), 2632-45. https://doi.org/10.1016/S2095-3119(16)61601-5

49. Widodo $Y$, Wahyuningsih S, Ueda A. Sweet Potato Production for Bio-ethanol and Food Related Industry in Indonesia: Challenges for Sustainability. Procedia Chem. 2015: 14, 493-500. https://doi.org/10.1016/j.proche.2015.03.066

50. Zhu F, Wang S. Physicochemical properties, molecular structure, and uses of sweetpotato starch. Trends Food Sci. Technol. 2014: 36(2), 68-78. https://doi.org/https://doi.org/10.1016/j.tifs.2014.01.008

51. He C, Zhang M, Guo C. 4D printing of mashed potato/purple sweet potato puree with spontaneous color change. Innovative Food Sci. Emerg. Technol. 2020: 59, 102250. https://doi.org/https://doi.org/10.1016/j.ifset.2019.102250

52. Villas-Boas F, Facchinatto WM, Colnago LA, Volanti DP, Franco, CML. Effect of amylolysis on the formation, the molecular, crystalline and thermal characteristics and the digestibility of retrograded starches. Int. J. Biol. Macromol. 2020: 163, 1333-43. https://doi.org/https://doi.org/10.1016/j.ijbiomac.2020.07.181

53. Na JH, Kim HR, Kim Y, Lee JS, Park HJ, Moon TW, Lee CJ. Structural characteristics of low-digestible sweet potato starch prepared by heat-moisture treatment. Int. J. Biol. Macromol. 2019: 151, 1049-57. https://doi.org/10.1016/j.ijbiomac.2019.10.146

54. Mohd Hanim AB, Chin NL, Yusof YA. Rheological characterisation of malaysian varieties of sweet potato doughs using large and small deformation measurements. Int. J. Food Prop. 2015: 18(5), 963-77. https://doi.org/10.1080/10942912.2014.910671

55. Sebben JA, Trierweiler LF, Trierweiler JO. Orange-Fleshed Sweet Potato Flour Obtained by Drying in Microwave and Hot Air. J. Food Process. Preserv. 2017: 41(1), 1-8. https://doi.org/10.1111/jppp.1274

56. Santiago DM, Matsushita K, Noda T, Tsuboi K, Yamada D, Murayama D, Yamauchi H. Effect of purple sweet potato powder substitution and enzymatic treatments on bread making quality. Food Sci. Technol. Res. 2015:21(2),15965. https://doi.org/10.3136/fstr.21.159 
57. Santiago DM, Matsushita K, Tsuboi K, Yamada D, Murayama D, Kawakami S, Yamauchi H. Texture and structure of bread supplemented with purple sweet potato powder and treated with enzymes. Food Sci. Technol. Res. 2015:21(4),537-48. https://doi.org/10.3136/fstr.21.537

58. Krishnan JG, Menon R, Padmaja G, Sajeev MS, Moorthy SN. Evaluation of nutritional and physico-mechanical characteristics of dietary fiber-enriched sweet potato pasta. Eur. Food Res. Technol. 2012:234(3),467-76. https://doi.org/10.1007/s00217-011-1657-8

59. Liao L, Liu H, Gan Z, Wu W. Structural properties of sweet potato starch and its vermicelli quality as affected by heat-moisture treatment. Int. J. Food Prop. 2019:22(1),1122-33. https://doi.org/10.1080/10942912.2019.1626418

60. Senanayake SA, Ranaweera KKDS, Gunaratne A, Bamunuarachchi A. Application of Hydrothermally Modified Sweet Potato Starch as a Substitute Additive for Soup Mixture. J. Food Process. 2014:15.https://doi.org/10.1155/2014/904125

61. Akintayo OA, Obadu JM, Karim OR, Balogun MA, Kolawole FL, Oyeyinka SA. Effect of replacement of cassava starch with sweet potato starch on the functional, pasting and sensory properties of tapioca grits. LWT Food Sci. Technol. 2019:111, 513-9. https://doi.org/10.1016/j.Iwt.2019.05.022

62. Xiang Z, Ye F, Zhou Y, Wang L, Zhao G. Performance and mechanism of an innovative humidity-controlled hot-air drying method for concentrated starch gels: A case of sweet potato starch noodles. Food Chem. 2018:269(2),193201. https://doi.org/10.1016/j.foodchem.2018.06.153

63. Santiago DM, Kawashima Y, Matsushita K, Noda T, Pelpolage S, Tsuboi K, Yamauchi H. Noodle qualities of fresh pasta supplemented with various amounts of purple sweet potato powder. Food Sci. Technol. Res. 2016:22(3), 307-16. https://doi.org/10.3136/fstr.22.307

64. Kadiri O, Gbadamosi SO, Akanbi CT. Extraction kinetics, modelling and optimization of phenolic antioxidants from sweet potato peel vis-a-vis RSM, ANN-GA and application in functional noodles. J. Food Meas. Charact. 2019:13(4),3267-84. https://doi.org/10.1007/s11694-019-00249-7

65. Ibitoye WO, Afolabi MO, Otegbayo BO, Akintola AC. Preliminary Studies of the Chemical Composition and Sensory Properties of Sweet Potato Starch-Wheat Flour Blend Noodles. Niger. Food J. 2013:31(2),48-51. https://doi.org/10.1016/s0189-7241(15)30076-x

66. Liao L, Wu W. Fermentation Effect on the Properties of Sweet Potato Starch and its Noodle's Quality by Lactobacillus plantarum. J. Food Process Eng. 2017:40(3). https://doi.org/10.1111/jpe.12460

67. Musyoka JN, Abong GO, Mbogo DM, Fuchs R, Low J, Heck S, Muzhingi, T. Effects of Acidification and Preservatives on Microbial Growth during Storage of Orange Fleshed Sweet Potato Puree. Int. J. Food Sci. 2018. https://doi.org/10.1155/2018/8410747

68. Malavi DN, Muzhingi T, Abong GO. Good manufacturing practices and microbial contamination sources in orange fleshed sweet potato puree processing plant in Kenya. Int. J. Food Sci. 2018. https://doi.org/10.1155/2018/4093161

69. Ginting E, Yulifianti R. Characteristics of Noodle Prepared from Orange-fleshed Sweet Potato, and Domestic Wheat Flour. Procedia Food Sci. 2015:3,289-302. https://doi.org/10.1016/j.profoo.2015.01.032

70. Lago CC, Liendo-Cárdenas M, Noreña CPZ. Thermodynamic sorption properties of potato and sweet potato flakes. Food Bioprod. Process. 2013:91(4),389-95. https://doi.org/10.1016/j.fbp.2013.02.005

71. Zou H, Xu L, Xu Z, Xie W, Wang Y, Liao X, Kong X. Effects of ultra-high temperature treatment and packages on baked purple sweet potato nectar. LWT Food Sci. Technol. 2018: 94(607), 129-35. https://doi.org/10.1016/j.Iwt.2018.04.037

72. Obradović V, Babić J, Šubarić D, Ačkar Đu, Jozinović A. Improvement of nutritional and functional properties of extruded food products. J. Food Nutr. Res. 2014:53(3),189-206.

73. Marangoni Júnior L, Ito D, Ribeiro SML, Silva MG, Alves RMV. Stability of $\beta$-carotene rich sweet potato chips packed in different packaging systems. LWT Food Sci. Technol. 2018:92, 442-50. https://doi.org/10.1016/j.Iwt.2018.02.066

74. Lim PK, Jinap S, Sanny M, Tan CP, Khatib A. The influence of deep frying using various vegetable oils on acrylamide formation in sweet potato (Ipomoea batatas L. Lam) chips. J. Food Sci. 2014:79(1). https://doi.org/10.1111/1750-3841.12250

75. Qiao F, Huang LL, Xia WS. A study on microwave vacuum dried re-structured lychee (Litchi chinensis Sonn.) mixed with purple sweet potato (Ipomoea batatas) snacks. Food Bioprod. Process. 2012:90(4),653-8. https://doi.org/10.1016/j.fbp.2012.05.002

76. Yang JH, Park HY, Kim YS, Choi IW, Kim SS, Choi HD. Quality characteristics of vacuum-fried snacks prepared from various sweet potato cultivars. Food Sci. Biotechnol. 2012:21(2),525-30. https://doi.org/10.1007/s10068-0120067-4 
77. Mussoline WA, Bohac JR, Boman BJ, Trupia S, Wilkie AC. Agronomic productivity, bioethanol potential and postharvest storability of an industrial sweetpotato cultivar. Ind. Crops Prod. 2017:95,96-103. https://doi.org/10.1016/j.indcrop.2016.10.013

78. Zuo S S, Niu DZ, Ning TT, Zheng ML, Jiang D, Xu CC. Protein Enrichment of Sweet Potato Beverage Residues Mixed with Peanut Shells by Aspergillus oryzae and Bacillus subtilis Using Central Composite Design. Waste Biomass Valorization. 2018:9(5), 835-44. https://doi.org/10.1007/s12649-017-9844-x

79. Li S, An Y, Fu W, Sun X, Li W, Li T. Changes in anthocyanins and volatile components of purple sweet potato fermented alcoholic beverage during aging. Food Res. Int. 2017:235-40 http:dx.doi.org/10.1016/j.foodres.2017.08.041

80. Ray RC, Panda SK, Swain MR, Sivakumar PS. Proximate composition and sensory evaluation of anthocyanin-rich purple sweet potato (Ipomoea batatas L.) wine. Food Sci. Technol. 2011: 452-8. http:10.1111/j.13652621.2011.02861.x

81. Lee JY, Im YK, Ko HM, Chin JE, Kim IC, Lee HB, Bai S. Direct utilization of purple sweet potato by sake yeasts to produce an anthocyanin-rich alcoholic beverage. Biotechnol. Lett. 2015: 37(7), 1439-45. https://doi.org/10.1007/s10529-015-1811-7

82. Li S, An Y, Fu W, Sun X, Li W, Li T. Changes in anthocyanins and volatile components of purple sweet potato fermented alcoholic beverage during aging. Food Res. Int. 2017 Aug:23540.https://doi.org/10.1016/j.foodres.2017.08.041

83. Humia BV, Santos KS, Schneider JK, Leal IL, Abreu Barreto G, Batista T, Padilha FF. Physicochemical and sensory profile of Beauregard sweet potato beer. Food Chem. 2020:312,126087. https://doi.org/10.1016/j.foodchem.2019.126087

84. Dwiyanti G, Siswaningsih W, Febrianti A. Production of purple sweet potato (Ipomoea batatas L.) juice having high anthocyanin content and antioxidant activity. J. Phys. Conf. Ser. 2018: 1013(1). https://doi.org/10.1088/1742$6596 / 1013 / 1 / 012194$

85. Zhu Z, Yuan F, Xu Z, Wang W, Di X, Barba FJ, Koubaa M. Stirring-assisted dead-end ultrafiltration for protein and polyphenol recovery from purple sweet potato juices: Filtration behavior investigation and HPLC-DAD-ESI-MS2 profiling. Sep. Purif. Technol. 2016: 169, 25-32. https://doi.org/10.1016/j.seppur.2016.05.023

86. Sato $\mathrm{Y}$, Han J, Fukuda H, Mikami S. Enhancing monoterpene alcohols in sweet potato shochu using the diglycoside-specific $\quad \beta$-primeverosidase. J. Biosci. Bioeng. 2018:125(2),218-23. https://doi.org/10.1016/j.jbiosc.2017.08.012

87. Panda SH, Ray RC. Lactic acid fermentation of $\beta$-carotene rich sweet potato (Ipomoea batatas L.) into lacto-juice. Plant Foods Hum. Nutr. 2007: 62(2), 65-70. https://doi.org/10.1007/s11130-007-0043-y

88. Afiati F, Priadi G, Setiyoningrum $F$. The improvement of functional food in yogurt enriched with purple sweet potato (Ipomea batatas var. Ayamurasaki). J. Indones. trop. anim. agric. 2018:43(2),159-68. https://doi.org/10.14710/jitaa.43.2.159-168

(c) 2021 by the authors. Submitted for possible open access publication under the terms and conditions of the Creative Commons Attribution (CC BY NC) license (https://creativecommons.org/licenses/by-nc/4.0/). 